\title{
Amor e paixão como facetas da educação: a relação entre escola e apropriação do saber
}

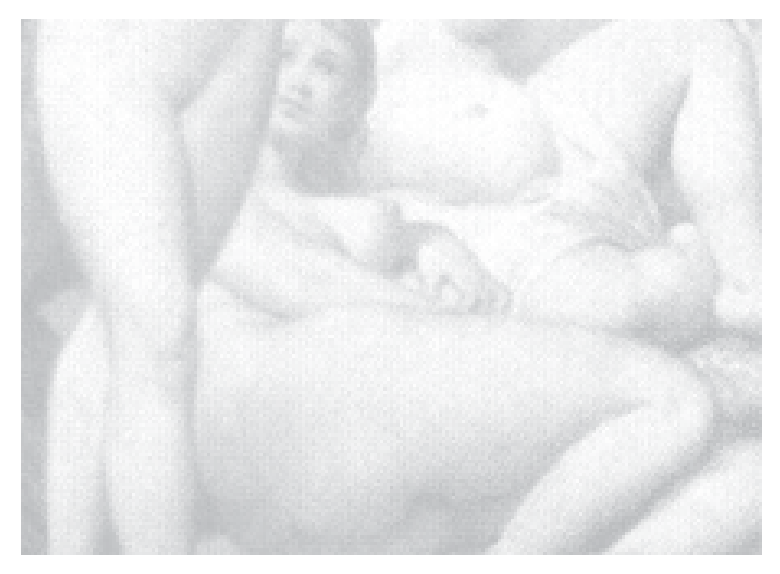

Sandra Soares Della Fonte ${ }^{1}$

DELLA FONTE, S.S. Love and passion as facets of education: the relationship between school and appropriation of knowledge. Interface - Comunic., Saúde, Educ., v.11, n.22, p.327-42, mai/ago 2007.

This article accepts the general proposition that love and passion are essential elements of the school education practice. However, contrary to the contemporary trends that argue that the loving facet of education dismisses truth and the objective knowledge and takes place as a linguistic experience, I advocate that the primordial Eros of school education is not effective without objective knowledge and its appropriation. To develop this idea, I borrow some of Plato's considerations on love in his classical text Symposium in order to rethink them based on the reflections about passion in Marx's Economical and Philosophical Manuscripts.

KEY WORDS: Love. Knowledge. School instruction.

Este artigo parte da proposição geral de que o amor e a paixão são elementos essenciais da prática educativa escolar. Contudo, ao contrário de algumas tendências contemporâneas que sustentam que a face amorosa da educação repele a verdade e o conhecimento objetivo, e se realiza como uma experiência lingüística, defendo que o Eros primordial da educação escolar não se efetiva quando se abre mão do conhecimento objetivo e da sua apropriação. Para desenvolver essa idéia, tomo emprestadas algumas considerações de Platão sobre o amor no clássico texto $O$ Banquete, a fim de repensá-las com base nas reflexões de Marx sobre a paixão, nos Manuscritos Econômico-Filosóficos.

PALAVRAS-CHAVE: Amor. Conhecimento. Educação escolar.

\footnotetext{
${ }^{1}$ Filósofa; doutora em Educação; professora, departamento de Ginástica, Universidade Federal do Espírito Santo (UFES). Vitória, ES. <sdellafonte@uol.com.br>
} 
Prometeu: Graças a mim, os homens não mais desejam a morte. [...] Além disso, consegui que eles participem do fogo celeste [...] e desse mestre aprenderão muitas ciências e artes.

Ésquilo

A habitação-luz que Prometeu, em Ésquilo, denota como uma das maiores dádivas pelas quais ele fez do selvagem um homem, cessa de existir para o trabalhador. Marx (2004, p.140)

São bastante recorrentes, no imaginário social, as associações entre a prática educativa escolar e o amor. Essas associações ganham diversas nuanças; podem, por exemplo, assumir um viés religioso (à semelhança do sacerdote, o professor aparece como aquele que, por amor, abraça a missão de ensinar e assume todos os sacrifícios de sua vocação) ou um sentido maternal (a profissão docente como vocação naturalmente feminina).

No Brasil, uma das relações clássicas entre educação e amor foi celebrizada por Paulo Freire que, na afirmação da liberdade e contra qualquer tipo de domesticação, proclamou a educação como "[...] um ato de amor, por isso, um ato de coragem. Não pode temer o debate. A análise da realidade. Não pode fugir à discussão criadora, sob pena de ser uma farsa" (Freire, 1989, p.96). Contudo, o caráter progressista que ganha essa afirmação da educação como um ato de amor em Paulo Freire se perde na proposição de Gabriel Chalita (2003) de uma "pedagogia do amor", voltada para a preparação para o mundo competitivo.

$\mathrm{Na}$ pesquisa acadêmica contemporânea, destaco o argumento de dois autores que relacionam a educação e o amor. O primeiro deles é o chileno Humberto Maturana, com sua proposta da biologia do amor. Segundo esse autor, o ser humano surge com a linguagem e vive sempre em um conversar. Por sua vez, a essa condição se associa o amor, "[...] emoção que constitui o espaço de ações em que se estabelece o modo de viver hominídeo, a emoção central na história evolutiva que nos dá origem" (Maturana, 1998, p.97). Maturana considera que o amor é a emoção primordial da vida que funda o social, visto que estabelece a aceitação do outro, o seu reconhecimento como existência legítima. Assim, como aproximação, aceitação mútua (Maturana, 1998), o amor instaura a convivência que se realiza pelo conversar.

Maturana (1998, p.98) declara que é a existência humana na linguagem que configura os diversos domínios de realidade; logo, a realidade é "uma proposição explicativa da experiência humana". Além disso, o autor assevera que os seres humanos não se referem a uma realidade externa independente do seu próprio observar. A resolução de Maturana de colocar a "objetividade entre parênteses" atende a esse preceito que, a seu ver, contribui para consolidar a convivência amorosa entre as pessoas. Por não existir uma realidade externa a quem recorrer, "[...] os diferentes pontos de vistas são válidos nos diferentes domínios, porque são baseados em preceitos diferentes" (Maturana, 1998, p.154). Na acepção do autor, 
qualquer tentativa de definir uma posição que tenha razão em detrimento de outra que se equivoca provoca a negação mútua e vai contra a constituição biológica amorosa do ser humano. Conhecer é, portanto, uma construção da linguagem, ou seja, é resultado do "domínio de coordenações condutais coordenadas" (Maturana, 1998, p.96). Maturana entende que, como fenômeno social, a educação tem seu fundamento no amor e seu centro é o conviver. Neste contexto, o professor é "Alguém que se aceita como guia na criação deste espaço de convivência" (Maturana, 1990, p.2), que produz ações comuns e mudanças conjuntas. A educação preservaria, deste modo, o traço biológico amoroso do ser humano.

Em uma perspectiva diferenciada dos argumentos de Maturana, Larrosa (2001) sugere pensar a educação como experiência de sentido. Para ele, a experiência não se confunde com a informação, a opinião, o trabalho; ela é o que nos passa, o que nos acontece, o que nos toca. O sujeito da experiência é, na sua visão (Larrosa, 2001, p.6), um "território de passagem", "ponto de chegada", espaço do acontecer. Não se define o sujeito da experiência pela sua atividade, mas sim pela sua condição passional, ou seja, sua passividade, abertura essencial, receptividade ao que the chega e lhe sucede. Nesse sentido, segundo Larrosa, a experiência é paixão, porque é, essencialmente, padecimento; o sujeito da experiência não é agente, é paciente, é "sofredor, padecente, receptivo, interpelado, submetido" (Larrosa, 2001, p.7).

De acordo com Larrosa (2001), o saber da experiência não é o da informação, da técnica, do trabalho e da ciência; ele se dá na relação entre conhecimento e vida humana, como

\footnotetext{
[...] aprendizagem no e pelo padecer, no e por aquilo que nos acontece [...] o que se adquire no modo como alguém vai respondendo ao que vai lhe acontecendo ao largo da vida e no modo como vamos dando sentido ao acontecer do que nos acontece. No saber da experiência, não se trata da verdade do que são as coisas, mas do sentido e do sem-sentido do que nos acontece (Larrosa, 2001, p.9).
}

Se a educação é entendida como uma experiência de sentido, o saber educacional também se vincula, segundo o autor, ao exercício de atribuição do sentido e compartilha outras características com o saber da experiência em geral: é finito, estreitamente articulado à existência de um indivíduo ou uma comunidade em particular - "Por isso o saber da experiência é uma saber particular, subjetivo, relativo, contingente, pessoal" (Larrosa, 2001, p.9). Duas pessoas podem enfrentar um mesmo acontecimento e não ter a mesma experiência, pois o sentido ao que lhes sucedeu pode ser diferenciado. Contra o experimento enaltecido pela ciência moderna (genérico, repetível, previsível, que produz acordo e consenso), a experiência afirma sua singularidade, sua não repetitividade, sua incerteza, sua produção da diferença e pluralidade. Ela expressa não apenas que o ser humano confere sentido ao que the sucede por meio de palavras, mas que ele próprio "[...] se dá na palavra e como palavra" (Larrosa, 2001, p.2). 
Segundo Larrosa, a educação é essa experiência que abre mão da verdade e privilegia o exercício demiúrgico da linguagem que ocorre em uma situação vivencial singular, que toma o sujeito, ou seja, faz dele um ser passional.

Os caminhos trilhados por Maturana e Larrosa quando declaram o entrelaçamento entre educação e amor/paixão são distintos. No entanto, salta aos olhos o fato de que, em ambos os casos, a face amorosa da educação repele a verdade e o conhecimento objetivo e se efetiva como uma experiência lingüística (ou de atribuição de sentido, pelo sujeito singular, ao que lhe acontece, ou de conversação que aceita o outro como outro $e$ coordena suas condutas).

Neste artigo, corroboro a proposição geral de que o amor e a paixão são elementos essenciais da educação escolar e, portanto, do trabalho pedagógico do professor. Contudo, ao contrário dos autores citados, defendo que o Eros primordial da educação escolar se efetiva na própria especificidade do processo educativo. Isso significa que não é possível falar da dimensão amorosa da escola quando se abre mão da verdade e do conhecimento objetivo. Para desenvolver essa idéia, tomo emprestadas algumas considerações de Platão sobre o amor (Eros) no clássico texto $O$ Banquete, a fim de repensá-las com base nas reflexões de Marx sobre a paixão nos Manuscritos Econômico-Filosóficos.

\section{O Eros de Platão}

Platão escreve sobre o amor em vários textos e sob perspectivas diferentes. Aqui não se pretende mapear esse tratamento diferenciado ou elaborar comparações, mas sim extrair do texto $O$ Banquete algumas considerações que permitam, nos limites possíveis de um artigo, evidenciar o sentido platônico do Eros como um agente educativo.

No texto em questão, Platão relata um encontro festivo na casa de Agatão, no qual os convivas foram conclamados, no momento do simpósio (bebida coletiva após a refeição), a fazerem um discurso de louvor ao amor. Como de praxe, Sócrates teria observado que, antes de enumerar as obras do amor, dever-se-ia perguntar o que é o amor.

Vários convidados fizeram seu discurso, mas priorizo apenas o de Sócrates.

Um dos primeiros elementos de destaque do discurso socrático está em sua apresentação do Eros como força cósmica que perpassa todos os seres. $\mathrm{O}$ amor remete a algo, é sempre amor de alguma coisa. A relação amorosa se volta para algo do qual se carece. Portanto, para Sócrates/Platão, o amor é desejo, e o desejo é carência e necessidade do que não se tem: "[...] o de que se carece; eis, precisamente, o objeto de desejo e do amor" (Platão, 1987, 200e).

$\mathrm{O}$ amor atravessa a condição humana à medida que ela se apresenta como incompletude e falta; esse caráter faz do ser humano um ser de desejo. Deste modo, o amor é um movimento, visto que estabelece uma relação que se volta para o não-eu, ou seja, para aquilo do qual se necessita e em nós não se encontra. Além disso, ele também se dirige para os meios de sua aquisição, para a satisfação dessa carência. Eros parte da privação e almeja a plenitude. Nesse sentido, ele envolve, ao mesmo tempo, a passividade de ser 
afligido pela carência $e$ a atividade desejante de saciar essa privação. Em Platão, o sentimento de não-acabamento humano tem como fonte "[...] a incompletude intrínseca à condição de alma decaída" (Pessanha, 1990, p.94) que, ao encarnar em um corpo, esquece-se da contemplação das coisas existentes na sua forma pura, que lhe foi possível no mundo das idéias, mundo no qual se encontrava antes de habitar o corpo. A perda do conhecimento adquirido na vida anterior à encarnação da alma é sentida como nostalgia de um mundo perfeito diante da existência corpórea na multiplicidade do mundo dos sentidos.

Outro elemento de grande vigor na reflexão platônica em $O$ Banquete é a natureza contraditória e instável de Eros. Na tradição mitológica grega, como deus da união e da afinidade universal, para se desenvolver, Eros precisa do seu adversário Anteros, deus da antipatia e da aversão. Poetas narram que Vênus queixou-se à deusa Têmis que seu filho Eros não crescia, permanecia criança. Têmis lhe teria respondido que ele não cresceria enquanto ela não tivesse outro filho e, portanto, desse a Eros um irmão; assim, para Eros crescer, Vênus concebeu Anteros (Commelin, 2000). Como carência e desejo, o Eros platônico é impulso que remete a um outro e implica, necessariamente, o reconhecimento do não-eu, da negatividade.

Se, por um lado, Platão preserva o viés contraditório do amor da tradição grega, por outro, ele inova em, pelo menos, dois aspectos: ele recria o mito de nascimento de Eros e retira desse deus sua aura divina. Para ele, o amor não é um deus, mas um intermediário entre mortais e imortais, ou seja, um gênio, um demônio (em grego, dáimon). Esse termo não tem sentido pejorativo. Nesse contexto, refere-se ao elo entre deuses e mortais. A função demoníaca

Interpreta e leva para os deuses o que vai dos homens, e, para os homens, o que vem dos deuses [...]. Colocado entre ambos, ele preenche esse intervalo, permitindo que o Todo se ligue a si mesmo. [...]. (Platão, $1987,202 e-203 a$ )

O caráter mediador de Eros pode ser mais bem compreendido com o mito de seu nascimento, que teria sido contado a Sócrates por Diotima. Segundo a sábia mulher, os deuses realizaram um banquete para comemorar o nascimento de Afrodite. Dentre eles, encontrava-se Poro (representava a riqueza e o expediente). No entanto, Penia (a pobreza) chegou ao final da festa para mendigar e viu Poro embriagado e dormindo. Diante da sua falta de recursos, Penia aproveitou a oportunidade e concebeu um filho com Poro - Eros. Sendo filho de Poro e Penia, da riqueza e da indigência, Eros herdou características de ambos: não é belo nem feio, não é bom nem mau, não é pobre nem rico; essa condição o permite trilhar o intervalo de um extremo ao outro. Assim, o Eros platônico é um demônio que medeia a relação vertical entre deuses e mortais. O caráter demoníaco de Eros é ser mediador entre desiguais e, como tal, cumprir a função de coesão do cosmo.

Como nem os sábios (por já possuírem a sabedoria), nem os ignorantes (porque ignoram que não sabem) buscam a sabedoria, Eros se encontra entre uns e outros e, por isso, pode se dedicar à filosofia: 
A sabedoria é o que há de mais belo. Ora, sendo Eros amante do belo, necessariamente será filósofo ou amante da sabedoria, e, como tal, se encontra colocado entre os sábios e os ignorantes. (Platão, 1987, 204b)

Daí se fala de uma ascese erótica progressiva em Platão, ou seja, de caminhos ou graus do amor que unem a carência à completude, o mortal ao divino, a feiúra à beleza, a ignorância à sabedoria. A ascese erótica erige uma ponte da beleza múltipla e sensível à beleza ideal do mundo inteligível. $\mathrm{Na}$ ascese erótica, passa-se "[...] do plano das relações afetivas entre as pessoas para o plano da relação afetivo-intelectual entre sujeitos e verdade [...]" (Pessanha, 1987, p.85) Por isso, o Eros é um agente educativo. Ele não é sábio tampouco um completo ignorante, conhece o que ignora. Por ter ciência da sua insciência, ele deseja o saber, ele é amante da sabedoria. Só Eros pode ser filósofo. Assim, para Platão, o amor não se contrapõe ao processo de conhecimento, mas é seu elemento motor. A reflexão plena não cala o amor; pelo contrário, ela não se realiza sem ele: Eros e Sophia entrelaçam-se. O amor supremo transmuta-se em Philia (amizade).

A ascese erótica de Platão também consiste em superar a própria limitação mortal. Quando amam, os mortais se aproximam dos deuses. Fecundos do corpo, os seres humanos procriam filhos. Férteis da alma, concebem a sabedoria e a virtude. Pela procriação (seja de filhos do corpo ou da alma), os mortais participam da eternidade e da imortalidade dos deuses.

Platão considera problemático o amor que permanece preso ao apelo da impaciência sensível e imediata. O discípulo socrático Alcebíades representa, em $O$ Banquete, esse amor no seu degrau mais inferior, por voltar sua atenção para Sócrates e pretender, por meio de artimanhas, prender o mestre a sua paixão (Pessanha, 1990, 1987). Uma das lições desse clássico texto platônico é que o verdadeiro amante não escraviza o amado, mas o conduz à sabedoria.

\section{Amor e paixão nos Manuscritos Econômico-Filosóficos}

Se tu amas sem despertar amor recíproco, isto é, se teu amar, enquanto amar, não produz o amor recíproco, se mediante tua externação de vida (Lebensäusserung) como homem amante não te tornas homem amado, então teu amor é impotente, é uma infelicidade. $\operatorname{Marx}(2004$, p.161)

Ao indagar como o amor e a paixão são abordados por Marx nos Manuscritos de 1844, cabe uma observação inicial. Pinçar qualquer tema presente nos Manuscritos Econômico-Filosóficos como objeto de análise demanda alguns cuidados em função de uma série de elementos, em especial, das características e do contexto desses escritos na trajetória intelectual de Marx.

Os Manuscritos apresentam idéias embrionárias ao entrelaçar elementos daquilo que, mais tarde, Lênin considerou ser as três fontes do marxismo: a filosofia alemã, o socialismo francês e a economia política inglesa. Algumas dessas idéias foram aprofundadas ou, mesmo, revistas por Marx em obras 
posteriores. Sem perder de vista as cautelas necessárias em relação a escritos da teoria marxiana em seu momento inicial, tomo os Manuscritos conforme sugere Frederico (1995): anotações nas quais há uma formulação provisória $e$ incipiente de uma ontologia materialista.

Nos Manuscritos, as reflexões marxianas sobre o Eros trazem a marca de uma certa apropriação da filosofia de Feuerbach e aparecem vinculadas, de modo especial, a considerações sobre os sentidos e sentimentos humanos. Em função de sua proximidade com a filosofia feuerbachiana, Marx (2004) chega mesmo a afirmar que a sensibilidade é a base de toda ciência. Se, por um lado, o sensualismo feuerbachiano representava um confronto com a filosofia especulativa hegeliana, por outro, como observa Frederico (1995), a exaltação do sensível fomentou uma ontologia empirista da qual, em muitos momentos, Marx não conseguiu se desvencilhar. A equivalência entre ser objetivo e ser sensível ilustra isso: o real é entendido por Marx (2004), neste momento, como aquilo que é objeto dos sentidos.

Contudo, como observa Frederico (1995), essa aproximação não impediu Marx de assimilar, com certa liberdade, as reflexões feuerbachianas e, inclusive, elaborar inovações impensáveis para esse filósofo. Isso ocorreu, fundamentalmente, com a eleição do trabalho, "atividade vital consciente", como centro das suas reflexões.

Na luta pela existência, o ser humano é impelido a produzir os meios para satisfazer as suas necessidades. O trabalho consiste no metabolismo entre ser humano e natureza. Porém, falar da relação do ser humano com a natureza implica, para Marx, afirmar que "[...] a natureza está interconectada consigo mesma, pois o homem é uma parte da natureza" (Marx, 2004, p.84). A dimensão natural do ser humano indica sua condição corpórea, sensível e objetiva. Como tal, o ser humano compartilha com os outros seres uma faceta de passividade e de carência:

\footnotetext{
[...] ele é um ser que sofre, dependente e limitado, assim como o animal e a planta, isto é, os objetos de suas pulsões existem fora dele, como objetos independentes dele. Mas esses objetos são objetos de seu carecimento (Bedürfnis), objetos essenciais, indispensáveis para a atuação e confirmação de suas forças essenciais. (Marx, 2004, p.127)
}

Ao explicar o ser humano como ser natural, Marx apresenta algumas linhas gerais de sua ontologia: ser objetivo é padecer por ter seu ser fora de si. O desdobramento essencial dessa proposição é que ser objetivo é também ser objeto para um outro ser. Em outros termos, sofrer a carência de um objeto implica ser um objeto de necessidade para um outro. Portanto, com essa afirmação, Marx não apenas identifica ser e objetividade, mas também demarca o aspecto relacional da permanente interação objetiva entre seres efetivos como tais. Todo existente é objetivo e, portanto, faz parte de um complexo concreto e está em relações diversas e sempre determinadas com outros entes. Portanto, no seu conjunto, o ser é um processo histórico.

Nesse sentido, segundo Marx (2004), um ser não-objetivo é um não-ser: ele não tem necessidade de, nem é necessário para um outro; ele não carece de nenhum objeto e não é, para nenhum outro ser, objeto de necessidade; é 
atemporal. Logo, "Um tal ser seria, em primeiro lugar, o único ser, não existiria nenhum ser fora dele, ele existiria isolado e solitariamente" (Marx, 2004, p.127-8).

Por outro lado, Marx sublinha que o ser humano é um ser natural humano. A tessitura do humano se dá por meio da sua atividade vital. No e pelo trabalho, o ser humano imprime na natureza seu próprio fim, originando uma nova objetividade: a natureza humanizada. Ao operar sobre a natureza, o ser humano engendra um mundo de objetivações externas a ele próprio, apesar de ser dele dependente. Pelo trabalho, o ser humano produz não só a si mesmo, mas se autoproduz como universalidade, como ser genérico, de tal forma que sua vida individual só se constitui como vida genérica. Somente com a apropriação desse universo de objetivações produzidas histórica e socialmente o indivíduo pode se formar.

A relação entre vida individual e a vida genérica delineada por Marx evita, de um lado, a afirmação de um indivíduo isolado e, de outro, uma concepção abstrata de sociedade. Nesse sentido, ele insiste que " $O$ indivíduo é o ser social" (Marx, 2004, p.107, grifo do autor), mesmo que a sua manifestação de vida imediata não seja realizada com outras pessoas.

De acordo com Marx, a essência humana desdobra-se para fora de si $e$ constitui novas objetividades. Nesse objetivar-se, o ser humano se afirma no mundo objetivo "Não só no pensamento [...], mas com todos os sentidos [...]" (Marx, 2004, p.110, grifo do autor). Por sua vez, são essas mesmas objetivações que ele precisa supra-sumir, também de forma omnilateral, a fim de confirmar a sua humanidade.

\footnotetext{
O homem se apropria da sua essência omnilateral de uma maneira omnilateral, portanto, como um homem total. Cada uma das suas relações humanas com o mundo, ver, ouvir, cheirar, degustar, sentir, pensar, intuir, perceber, querer, ser ativo, amar, enfim todos os órgãos da sua individualidade, assim como os órgãos que são imediatamente em sua forma como órgãos comunitários, são no seu comportamento objetivo ou no seu comportamento para com o objeto a apropriação do mesmo, a apropriação da efetividade humana [...]. (Marx, 2004, p.108)
}

A natureza do objeto $e$ a força humana essencial que a ela corresponde determinam como o objeto se torna objeto para o ser humano. As peculiaridades dos sentidos e sentimentos humanos dizem respeito às determinações do objeto $e$ ao modo peculiar de sua fruição: "Ao olho um objeto se torna diferente do que ao ouvido, e o objeto do olho é um outro que o do ouvido" (Marx, 2004, p.110, grifo do autor). Assim, o ser humano precisa orientar sua ação em direção às várias objetivações pelas suas propriedades e causalidades. Estas, por sua vez, delimitam as possibilidades de seu desfrute.

Ora, o fundamental é perceber que, na constituição do indivíduo, os sentidos e sentimentos são socialmente engendrados e se distanciam do mundo animal, constrangido pela necessidade imediata. Eles se humanizam à medida que se produzem objetivações humanas e estas são apropriadas em meio a relações sociais determinadas. Por isso, Marx (2004, p.110) afirma 
que é na relação com a riqueza objetivamente desdobrada da essência humana que se desenvolve a riqueza da sensibilidade humana subjetiva na forma, por exemplo, de "um ouvido musical, um olho para a beleza da forma". Com isso, enfatiza-se não apenas a necessidade do objeto (a natureza humanizada) na formação do sujeito, mas o próprio caráter histórico desse processo:

Pois não só os cinco sentidos, mas também os assim chamados sentidos espirituais, os sentidos práticos (vontade, amor etc.), numa palavra, o sentido humano, a humanidade dos sentidos, vem a ser primeiramente pela existência do seu objeto, pela natureza humanizada. A formação dos cinco sentidos é um trabalho de toda a história do mundo até aqui. (Marx, 2004, p.110)

O termo ser natural humano utilizado por Marx envolve uma dupla dimensão aparentemente excludente: revela o ser humano em seu padecimento como um ser de carências e em seu vigor rumo à satisfação de suas necessidades. Em Marx, a paixão condensa esse movimento humano de passividade e atividade:

\footnotetext{
O homem enquanto ser objetivo sensível é, por conseguinte, um padecedor, e, porque é um ser que sente o seu tormento, um ser apaixonado. A paixão (Leidenschaft, Passion) é a força humana essencial que caminha energicamente em direção ao seu objeto. (Marx, 2004, p.128)
}

A paixão possui, assim, uma dupla face: é "a dominação da essência objetiva em mim", mas também "a atividade da minha essência" (Marx, 2004, p.113). O tratamento dado por Marx tanto à paixão, como aos sentidos humanos, ultrapassa o meramente antropológico e assume a condição ontológica (Marx, 2004). Contudo, aqui cabe uma observação. Feuerbach (1972) já havia afirmado a dimensão ontológica da paixão; para ele, o intercâmbio amoroso (amor como paixão) instaura não apenas a sociabilidade humana, mas é critério da existência de todo e qualquer existente: somente existe aquilo que é objeto de uma paixão, de tal forma que não-ser e não-amar se equivalem.

Quando Marx sinaliza a condição ontológica dos sentimentos e sentidos, ele não define as relações intersubjetivas, em especial, as amorosas, como princípio gerador da sociabilidade humana e da existência em geral. Ter o seu ser fora de si é uma característica de todo ser objetivo; mas ser apaixonado é um traço que, em Marx, só cabe ao humano. Diferente de

2 Essa decisão é ratificada em $A$ sagrada família, quando Marx (1997) reage à tentativa de fazer do amor algo independente do ser humano, isto é, de falar do amor descolado do indivíduo que ama. Feuerbach, que define o amor como instituidor de ser, e de Platão, que trata o amor como força cósmica que perpassa todos os seres (apesar de assumir uma forma especial no ser humano), Marx circunscreve o amor ao âmbito humano ${ }^{2}$. O papel que as relações amorosas ganham em Feuerbach é deslocado, na teoria marxiana, para o trabalho: a atividade vital consciente instaura o âmbito da sociabilidade. Os sentidos e sentimentos não são anteriores ao ser humano; eles são constituintes do humano, apesar de serem ontologicamente secundários (em relação à prioridade do trabalho). 
O que Marx chama de paixão nos Manuscritos caracteriza a passividade e a atividade constitutiva do indivíduo ao se afirmar como ser social. A ele falta a determinação de seu ser materializada em objetivações historicamente produzidas; no entanto, essa falta o impulsiona em direção a essa externalidade que, ao ser apropriada, cria condições para novas objetivações. Dizer que homens e mulheres são seres apaixonados expressa, para o Marx dos Manuscritos, o modus operandi da sociabilidade humana instaurada pelo trabalho.

Nos Manuscritos de 1844, Marx também revela a natureza contraditória do trabalho: fonte de humanização, ele se transmuta, em relações sociais onde vigora a propriedade privada, na desefetivação da essência humana. A relação do trabalhador com o seu produto, a sua objetivação, é de estranhamento3: "[...] o objeto (Gegenstand) que o trabalho produz, o seu produto, se lhe defronta como um ser estranho, como um poder independente do produtor" (Marx, 2004, p.80, grifo do autor).

O trabalho alienado estabelece uma relação de estranhamento do ser humano com o produto $e$ a atividade de produção, com o próprio gênero humano (que se transforma em meio para a vida individual) e consigo mesmo. Quando o produto de seu trabalho se lhe apresenta como um objeto estranho, o mundo que o trabalhador cria diante de si se lhe torna alheio, se Ihe defronta de modo hostil, e, assim, ele próprio se torna mais pobre, o seu mundo interior pertence menos a si (Marx, 2004). Sob relações estranhadas, o fundamento da organização social é a luta, a guerra, a oposição hostil (Marx, 2004). Como resultado desse processo, há, para alguns, o refinamento das carências, enquanto, para os trabalhadores, resta o seu rebaixamento a limites grosseiros nos quais tudo o que ultrapassa a reprodução física se lhes apresenta como luxo (Marx, 2004), a comida só existe em sua faceta abstrata e não existe "nenhum sentido para o mais belo espetáculo" (Marx, 2004, p.11, grifo do autor). O trabalho estranhado avilta todas as forças humanas: as paixões e a sensibilidade se deterioram, transforma-se a "estupidez em entendimento, o entendimento em estupidez" (Marx, 2004, p.160).

Diante disso, Marx visualiza o comunismo como supra-sunção positiva da propriedade privada, como a emancipação completa das qualidades $e$ sentidos humanos. Sob o pressuposto do socialismo, Marx (2004, p.139) fala da "riqueza (Reichheit) das carências humanas" e, portanto, de um novo modo de produção e de um novo objeto da produção. Assim, ele vislumbra o enriquecimento da essência humana no qual " $O$ homem rico é simultaneamente o homem carente de uma totalidade da manifestação humana da vida. O homem, no qual a sua efetivação própria existe como necessidade (Notwendigkeit) interior, como falta (Not)" (Marx, 2004, p.112-3, grifo do autor). O ser humano rico é educado para usufruir a arte, apreciar a beleza, agir de modo estimulante e encorajador sobre os outros, trocar amor por amor (Marx, 2004).

\section{Educação e conhecimento: a escola e sua função demoníaca}

A fim de pensar a relação entre escola e conhecimento, tomo de empréstimo

\author{
${ }^{3}$ Em geral, nos \\ Manuscritos, Marx \\ distingue objetivação \\ (Entsäusserung) de \\ estranhamento/ \\ alienação \\ (Entfremdung), \\ apesar de usar \\ indistintamente esses \\ termos em alguns \\ momentos. Enquanto \\ o primeiro tem o \\ sentido positivo de \\ exteriorização \\ (produção de \\ objetivações \\ humanas), o segundo \\ refere-se à relação \\ social característica \\ de sociedades \\ baseadas na \\ propriedade privada, \\ nas quais o ser \\ humano não se \\ reconhece na sua \\ obra.
}


de Platão a noção de que o Eros cumpre um papel demoníaco, mediador, que conduz da ignorância ao saber, ou melhor, é a busca do saber e da verdade a partir do reconhecimento da sua ausência, do nosso não-saber. Além do caráter contraditório que lhe é característico, a ascese erótica é fundamentalmente educativa. Não é possível falar em acesso ao ou produção do conhecimento sem o amor, sem o desejo que, arrebatado pela carência, é levado a buscar a sua satisfação. A partir de Platão, gostaria de sugerir que a educação escolar possui uma faceta erótica vinculada ao desejo do saber. Reconheço que a discussão acerca do erotismo da prática educativa escolar pode tomar rumos diversos; contudo, essas discussões podem se perder se não situadas nas peculiaridades dessa prática social. É por essa razão que aqui defendo que o Eros primordial da educação escolar se efetiva na própria especificidade do processo educativo. Todavia, examino o significado dessa proposição geral, isto é, o seu conteúdo substancial, a partir das reflexões marxianas elaboradas nos Manuscritos de 1844.

A primeira questão que se coloca é por que o ser humano carece do saber, por que o saber é objeto de desejo humano. Ontologicamente, o saber é elemento essencial da práxis humana, desde o cotidiano até esferas de objetivações mais elaboradas e sistematizadas, como a ciência, a filosofia, a política $e$ as artes. Ao buscar meios para realizar fins postos no processo de trabalho, o ser humano necessita conhecer o sistema causal dos objetos, suas qualidades e propriedades, ele precisa desvelar as determinações do objeto a fim de guiar sua ação e o modo específico de transformá-lo. Desta maneira, como mencionado, o ser humano produz um universo de objetivações (conhecimentos, hábitos, valores, conceitos, idéias, formas de sentir etc.), um mundo de genericidade sem o qual não pode se formar como indivíduo. Para se constituir, ele precisa tornar essa produção objetivada parte de sua natureza.

Portanto, o ser humano aprende a se tornar humano e isso só é possível ao se apropriar do patrimônio de objetivações humanas. Quando isso ocorre, o ser humano reproduz em si mesmo as funções e aptidões criadas historicamente pela humanidade, convertendo-as em capacidades próprias e instaurando a possibilidade de produzir novas objetivações humanas.

Em sentido amplo, a educação consiste na produção do indivíduo como ser social, ou seja, ela equivale ao próprio processo de aprender a ser humano. Por essa razão, Saviani (1991) explica que a educação é exigência do e para o processo de trabalho, bem como ela própria é um processo de trabalho, por "[...] produzir, direta e intencionalmente, em cada indivíduo singular, a humanidade que é produzida histórica e coletivamente pelo conjunto dos homens" (Saviani, 1991, p.21). O objeto da educação diz respeito, para esse autor, à identificação dos elementos culturais que precisam ser assimilados pelos indivíduos para que se tornem humanos, e à descoberta dos meios mais adequados para se atingir esse objetivo. Desta forma, a educação porta uma dimensão amorosa, desejante, na qual o saber é, para o ser humano, uma ausência, uma necessidade que toca diretamente a sua condição de humano.

A dimensão erótica da educação se efetiva quando ela assume o que Platão chamava de papel demoníaco. Porém, trata-se de conceber, a partir 
de Marx, a relação vertical platônica do dáimon em termos horizontais. A ascese erótico-educativa não se dá entre deuses e mortais, entre mortais e divinos, mas entre seres humanos. O amor educativo é demoníaco porque estabelece a mediação entre o ser humano e o saber produzido por outras gerações e acumulado historicamente. Em outras palavras, ele é mediador entre o indivíduo e o gênero humano, entre a singularidade existencial e a universalidade genérica.

O erotismo da educação escolar ganha uma peculiaridade à medida que o papel primordial da instituição escolar consiste na socialização do saber sistematizado (conhecimento elaborado e não espontâneo, sistematizado $e$ não fragmentado, erudito e não popular). A escola precisa tornar esse saber assimilável, dosá-lo e seqüenciá-lo, no espaço escolar, ao longo de um tempo determinado, de modo que se passe de seu não-domínio para domínio (Saviani, 1991). O trabalho educativo escolar manifesta sua faceta erótica e, portanto, demoníaca quando é mediadora entre o saber espontâneo, popular, e o saber sistematizado, erudito. Não se trata de mediação unilateral que aniquila o saber espontâneo, mas de uma radicalização dos laços entre esses modos de conhecer. Por mais diversos que sejam, os tipos de saber possuem um traço comum: eles buscam, por meio de sua particularidade, apreender e representar a objetividade do mundo no intuito de orientar a ação humana rumo a alguns fins. Por certo, as formas sistematizadas de conhecimento são derivações dos modos espontâneos do conhecer. Contudo, isso não impede ao saber sistematizado de também possuir, em relação às crenças, valores, formas de sentir, hábito, idéias do viver espontâneo, uma autonomia relativa: ele pode confirmar $e$ desenvolver, assim como criticar essas objetivações da esfera cotidiana da vida social.

Nesse sentido, o acesso às formas elaboradas de conhecimento envolve o distanciamento do viver cotidiano e, ao mesmo tempo, uma nova aproximação no qual esse cotidiano pode ser redimensionado, reavaliado $e$ enriquecido. Por isso, "[...] o acesso à cultura erudita possibilita a apropriação de novas formas através das quais se podem expressar os próprios conteúdos do saber popular" (Saviani, 1991, p.29). Isso traz a possibilidade de os indivíduos reconstruírem as hierarquias das atividades cotidianas e os valores que as regem (Duarte, 1993). A ascese erótica da prática educativa escolar é, assim, de mão dupla: move-se do viver espontâneo para o universo das formas culturais elaboradas, e vice-versa.

A função demoníaca e, conseqüentemente, erótica da educação escolar também possibilita uma nova relação do indivíduo com as objetivações genéricas mais elaboradas. Marx (2004) considera que o ser humano não é apenas um ser de carências, ele também é sabedor de suas necessidades $e$ pode reconhecer a vida genérica como constitutiva da sua existência individual:

Mas o homem não é apenas ser natural, mas ser natural humano, isto é, ser existente para si mesmo (für sich selbst seiendes Wesen), por isso, ser genérico, que, enquanto tal, tem de atuar e confirmar-se tanto em seu ser quanto em seu saber. (Marx, 2004, p.128) 
Ser-para si implica que o ser humano se reconhece como ser apaixonado, acometido e tomado por carências, $e$ impulsionado a uma conduta ativa $e$ criadora de satisfação de suas necessidades. A consciência de si aparece, portanto, como consciência da dimensão social e genérica de sua singularidade existencial. Essa possibilidade de o ser humano ser para-si lhe permite conduzir sua vida mediante uma relação consciente com o gênero, que não se reduz apenas a um pensar alerta, mas abrange todas as faculdades humanas: "Essa relação não é uma relação só de pensamento, mas da própria vida, da atividade social dos homens" (Duarte, 1993, p.140). Em Marx, não se depuram, da ascese amorosa, a sensibilidade e os afetos em função da intelecção (como em Platão), mas se busca o enriquecimento do existir humano em sua omnilateralidade.

Essa passagem de uma existência em-si (não consciente) para a existência para-si exige do indivíduo o reconhecimento de que a generalidade humana é, para ele próprio, um carecimento, objeto de desejo. O forjar dessa relação enriquecida e consciente com o âmbito genérico do fazer-se humano demanda uma intervenção intencional e organizada. Também, neste caso, a prática pedagógica escolar revela sua face amorosa ao assumir a mediação entre a vivência espontânea e a condução consciente da vida "[...] pela relação também consciente com o processo histórico de objetivação universal e livre do gênero humano" (Duarte, 1993, p.119). De acordo com Duarte (1993), a prática pedagógica escolar não apenas permite o acesso a objetivações genéricas elaboradas, mas as torna, para o educando, uma necessidade para o seu pleno desenvolvimento. A educação escolar, portanto, é "um processo criador de carecimentos" (Duarte, 1993, p.189, grifo do autor). Por conseguinte, ao responder ao desejo humano em relação ao saber, a educação escolar organiza maneiras que lhe permitem cumprir sua função demoníaca de mediar o acesso a formas culturais elaboradas. Ao fazer isso, acaba por reforçar essa condição desejante e passional do ser humano.

A ascese erótica que Marx nos autoriza a pensar representa um caminho que se move entre conhecimentos espontâneos e formas culturais elaboradas, entre a particularidade do indivíduo e a universalidade do gênero, entre a existência em-si e a para-si, entre a satisfação de carecimentos e a produção de novos desejos. Somente ao cumprir essa tarefa mediadora (e, portanto, demoníaca) é que a educação escolar afirma homens e mulheres como seres passionais e abre horizontes para novas objetivações que respondam a esses novos desejos e carecimentos.

Nos Manuscritos, Marx denuncia que o estranhamento engendrado pelas relações capitalistas rompe a relação de reconhecimento do indivíduo com essa universalidade, porque torna o acesso à riqueza das objetivações humanas restrito a poucos, e faz da vida genérica apenas um meio de manutenção da existência física. O estranhamento corrói a vida humana em sua totalidade e, desta forma, liquida da práxis humana a sua paixão. Ela destrói o que aqui denominamos de função demoníaca da educação escolar, ao tornar o acesso ao saber privatizado.

Entretanto, a atmosfera ideológica contemporânea tende a encobrir esse fenômeno. Dissemina-se, hoje, a máxima de que se vive na "sociedade do conhecimento", "sociedade do conhecimento compartilhado" (Unesco, 2005, 
p.147), na qual a transmissão $e$ a difusão do conhecimento são consideradas funções vitais que garantem a sua sustentação. $O$ anúncio de que o padrão social contemporâneo tem, no conhecimento, seu núcleo estrutural e organizador convive com o fato de que $20 \%$ da população mundial são analfabetos (aproximadamente 875 milhões de pessoas). Além disso, a suposta valorização do conhecimento expressa, de fato, a sedução de um conhecimento cativo à sua aplicação imediata, velozmente degustado $e$ avaliado conforme sua capacidade de responder aos apelos da prática eficiente e útil, conveniente aos interesses manipulatórios do capital.

No plano da produção do conhecimento, diante da alegação pós-moderna de que a realidade é incognoscível (porque não existe ou não é acessível), toda efetividade é antropomorfizada. Aniquila-se a objetividade e se transmuta o estatuto ontológico em questão de conhecimento. Quando o em-si é suprimido, o seu conhecimento objetivo é desacreditado. Refuta-se, desta forma, a possibilidade de dizer algo sobre o mundo: o conhecimento é visto como constructo, e a verdade, como consenso.

Essa tendência de depreciação do conhecimento objetivo da atual agenda pós-moderna delineou-se ao longo das derrotas vividas pela esquerda política no século XX. No espaço deste artigo não é possível esmiuçar o seu curso histórico, mas registrar que, por um lado, destituída de qualquer horizonte emancipatório, a classe trabalhadora questiona a própria necessidade de uma teoria que busque desvendar os meandros e a dinâmica da realidade social. Por outro, quando o capitalismo revela a sua face mais perversa e sua impossibilidade de garantir uma vida digna a todos, qualquer teoria que assuma a tarefa de desvendar facetas do mundo objetivo precisa ser combatida e desacreditada.

No contexto de desvalorização do conhecimento objetivo, a escola é esvaziada em seu papel de socializar o saber e atrelada à mera aculturação cujo compromisso circunscreve-se simplesmente ao "modo como as coisas são ditas" (Rorty, 1994, p.353) e à valorização da experiência vivencial singular e imediata. A interdição do conhecimento objetivo e a redefinição do papel da escola em termos de exercícios meramente lingüísticos e de enaltecimento do vivido, plasmado no empírico, apresentam-se como um render-se à configuração histórica manipulada do capitalismo sob o disfarce de proposições avançadas e de esquerda. Contudo, de fato, esvazia-se a educação escolar da maioria, enquanto se aperfeiçoa e aprimora aquela dirigida para a educação das elites (Duarte, 2000). Sob o capitalismo, a eficiência da escola destinada aos trabalhadores ocorre quando ela não cumpre a sua função e nega o acesso ao conhecimento elaborado $e$ historicamente acumulado, ou o oferece de forma deteriorada.

Desta forma, a luta contra o estranhamento engendrado pelas relações capitalistas também se passa pela intolerância contra a desqualificação do saber. A prática educativa que não leva a novos carecimentos, a novas formas desejantes que enriquecem o sentido do humano, que apenas acultura aos valores hegemônicos, que renuncia sua função eminentemente demoníaca de socializar o saber científico, artístico, ético-político e filosófico, na verdade, abdica do Eros, cai no desamor. Não se trata aqui de conceber o desamor como relação sentimental imediata de desprazer ou 
constrangimento entre professor e aluno, mas "[...] de considerá-lo como a negação do desejo do professor e do aluno de/na apropriação do saber, fato que implica o esvaziamento da função da escola" (Loureiro, 2006, p.227).

Diante disso, ficam algumas provocações. Efetivar o Eros da e na educação envolve a evocação do Anteros dirigido, de forma intransigente, contra a degradação humana, contra o capital. Além disso, se à educação escolar cabe organizar os meios para satisfazer o desejo humano pelo saber, é preciso estar alerta a fim de que esses meios não reproduzam relações de estranhamento e, nesse sentido, contraponham-se ao objetivo posto. Assim, não se pode desviar do fato de que o uso da violência física no processo educativo, assim como do sarcasmo e da zombaria, despotencializa o desejo de saber. Da mesma forma, o estabelecimento de relações afetivas agradáveis e amistosas por parte do professor, mas que não se comprometem a estimular uma atitude apaixonada, ao mesmo tempo passiva e ativa, de padecimento e de vigor do aluno diante das ricas objetivações humanas, carreia um desamor sutil.

\section{Referências}

CHALITA, G. Educar é um ato de coragem e afeto. A Tribuna, Santos, 27 maio 2003. Disponível em: <http://www.chalita.com.br/textos_detalhe.asp?ID=27>. Acesso em: 7 set. 2006.

COMMELIN, P. Mitologia grega e romana. São Paulo: Martins Fontes, 2000.

DUARTE, N. Vigotski e o "aprender a aprender": crítica às apropriações neoliberais e pós-modernas da teoria vigotskiana. Campinas: Autores Associados, 2000.

A individualidade para si: contribuição a uma teoria histórico-social da formação do indivíduo. Campinas: Autores Associados, 1993.

FEUERBACH, L. Principles of the future philosophy. 1972. Disponível em: <http://www.marxists.org/ reference/archive/feuerbach/works/future/index.htm>. Acesso em: 4 set. 2006.

FREDERICO, C. O jovem Marx. São Paulo: Cortez, 1995.

FREIRE, P. Educação como prática da liberdade. 19.ed. Rio de Janeiro: Paz e Terra, 1989.

LARROSA, J. Notas sobre a experiência e o saber de experiência. In: SEMINÁRIO INTERNACIONAL DE CAMPINAS: a escola como centro do processo pedagógico, 1., 2001, Campinas. Disponível em: $<$ <ww.campinas.sp.gov.br/smenet/seminario/seminario_pronto_jorgelarrosa.htm>. Acesso em: 7 set. 2006.

LOUREIRO, R. Da teoria crítica de Adorno ao cinema crítico de Kluge: educação, história e estética. 2006. Tese (Doutorado em Educação) - Programa de Pós-Graduação em Educação, Universidade Federal de Santa Catarina, Florianópolis, 2006.

MARX, K. The holy family. 1997. Disponível em: <http://www.marxists.org/archive/marx/works/1845/holyfamily/index.htm>. Acesso em: 6 nov. 2005.

Manuscritos econômico-filosóficos. São Paulo: Boitempo, 2004.

MATURANA, H. O que é ensinar? Quem é um professor? Trecho final de aula gravado por Cristina Magro, transcrito por Nelson Vaz. Universidad de Chile, 27 jul. 1990. Disponível em:

$<w w w$. institutoser.com.br/new_site/faz_aconteser/oqueeensinar.doc>. Acesso em: 7 set. 2006.

Da biologia à psicologia. 3.ed. Porto Alegre: Artes Médicas, 1998. 
DELLA FONTE, S.S.

PESSANHA, J.A.M. A água e o mel. In: NOVAES, A. (Org.). O desejo. São Paulo/Rio de Janeiro: Companhia das Letras/Funarte, 1990. p.91-123.

Platão: as várias faces do amor. In: NOVAES, A. (Org.). Os sentidos da paixão. São Paulo/Rio de Janeiro: Companhia das Letras/Funarte, 1987. p.77-103.

PLATÃO. O banquete. In: Os pensadores. 4.ed. São Paulo: Nova Cultural, 1987.

RORTY, R. A filosofia e o espelho da natureza. Rio de Janeiro: Relume-Dumará, 1994.

SAVIANI, D. Pedagogia histórico-crítica: primeiras aproximações. São Paulo: Cortez/Autores Associados, 1991.

UNESCO. From the information society to knowledge societies. Unesco: Paris, 2005. Disponível em: <http://educationclearinghouse.nairobi-unesco.org/docs/Global_report_information_society_to_knowledge _societies.pdf>. Acesso em: 17 ago. 2006.

DELLA FONTE, S.S. Amor y pasión como facetas de la educación: la relación entre escuela y apropiación del saber. Interface - Comunic., Saúde, Educ., v.11, n.22, p.327-42, mai/ago 2007.

Este artículo acepta la tesis general que el amor y la pasión son elementos esenciales de la práctica de la educación escolar. Sin embargo, contrariamente a las tendencias contemporáneas que alegan que la faceta amorosa de la educación rechaza la verdad y el conocimiento objetivo y sucede como experiencia lingüística, defiendo que el Eros primordial de la educación escolar no logra sin el conocimiento objetivo y su apropiación. Para desarrollar esta idea, pido prestadas las consideraciones de Platón sobre el amor en su clásico texto El Banquete para repensarlas desde algunas reflexiones de Marx sobre la pasión, en los Manuscritos Económicos y Filosóficos.

PALABRAS CLAVE: Amor. Conocimiento. Educación escolar.

Recebido em 07/11/06. Aprovado em 26/04/07. 